\title{
Growth Regulation of Multi-Factor-Dependent Myeloid Cell Lines: IL-4, TGF- $\beta$ and Pertussis Toxin Modulate IL-3- or GM-CSF-Induced Growth by Controlling Cell Cycle Length
}

\author{
Shigeo Koyasu', Atsushi Miyajima², Ken-Ichi Arai², Fumikazu Oka- \\ jima $^{3}$, Michio $\mathrm{Ui}^{\mathbf{3}, 4}$ and Ichiro Yahara ${ }^{1}$ \\ ${ }^{1}$ Department of Cell Biology, The Tokyo Metropolitan Institute of Medical \\ Science, Tokyo 113; ${ }^{2}$ Department of Molecular Biology, DNAX Research In- \\ stitute of Molecular and Cellular Biology, Palo Alto, CA 94304-1104, U.S.A.; \\ ${ }^{3}$ Department of Physiological Chemistry, Faculty of Pharmaceutical Sciences, \\ Hokkaido University, Sapporo 060; and ${ }^{4}$ Department of Physiological \\ Chemistry, Faculty of Pharmaceutical Sciences, University of Tokyo, Tokyo \\ 113
}

\begin{abstract}
The stimulatory effects of lymphokines, interleukin 3 (IL-3), granulocyte-macrophage colony stimulating factor (GM-CSF) and interleukin 4 (IL-4), and the inhibitory effects of transforming growth factor $\beta$ (TGF- $\beta$ ) and the pertussis toxin, islet activating protein (LAP), on multi-factor-dependent myeloid cell lines were examined. The effects of IL-3 on a mast cell progenitor clone, IC2 were indistinguishable from those of GM-CSF with respect to their concentration-response curves for induction of DNA synthesis and capability to maintain cell growth for many months. IL- 4 acts differently on IC2 cells: the maximum level of DNA synthesis induced by IL-4 is always lower than that induced by IL-3 or GM-CSF and IL-4-induced proliferation is transient. IL-4, however, synergistically induced DNA synthesis of IC2 cells with limiting concentrations of IL-3 or GM-CSF. When IC 2 cells were cultured with saturating concentrations of IL-3, GM-CSF or a combination of both, the doubling time was $25 \pm 1 \mathrm{~h}$, whereas it decreased to $17 \pm 1 \mathrm{~h}$ when IL-4 was further added to the cultures. IAP reduced the DNA synthesis of IC2 cells induced by the above three growth factors. The doubling time of IC2 cells was $30 \pm 2 \mathrm{~h}$ when IC2 cells were cultured with sufficient concentrations of IL-3 in the presence of IAP. Cell cycle analysis revealed that the fraction of cells in Gl was decreased by IL-4 but was increased by IAP. TGF- $\beta$ also reduced IL-3-dependent DNA synthesis and increased the fraction of cells in Gl. The inhibitory effect on IL-3-dependent growth of IC2 cells was not increased when these cells were exposed simultaneously to TGF- $\beta$ and IAP. These results suggest that IL-3 and GMCSF stimulate the growth of IC2 cells through similar pathways and that IL-4 augments the action of IL-3 or GM-CSF by decreasing the Gl period. It is also suggested that IAP and TGF- $\beta$ retard the growth of IC 2 cells by increasing the
\end{abstract}

Abbreviations used: IL-3, interleukin 3; IL-4, interleukin 4; CM-CSF, granulocyte-macrophage colony-stimulating factor; TGF- $\beta$, transforming growth factor $\beta$; IAP, islet activating protein; G-protein, GTP-binding protein; NAD, nicotinamide adenine dinucleotide; SDS-PAGE, sodium dodecyl sulfatepolyacrylamide gel electrophoresis. 
fraction of cells in Gl.

IL-3 is a T-cell-derived growth factor which supports the growth and development of hematopoietic cells in vitro and generates multi-lineage colonies from bone marrow cells including granulocyte, macrophage, erythroid, megakaryocyte and mast cell colonies $(2,4,23,24,27)$. A number of cell lines which grow in response to IL-3 have been established and many of them also respond to another hematopoietic growth factor, $\operatorname{GM}-\operatorname{CSF}(3,8,28)$. In addition, recent studies have revealed that IL-4 also affects the growth of IL-3-dependent cell lines $(8,10,14,25)$. In these cell lines, IL-3, GM-CSF and IL-4 each bind to separate cell surface receptors on the same cells $(16,17,21,22,28)$. An IL-3-dependent cell line, IC2, was established from a spleen of a DBA $/ 2$ mouse and has many features in common with mast cells (6-8).

TGF- $\beta$ is a factor derived from various cell types which stimulates the growth of some cell types, including osteoblasts and Schwann cells, and inhibits that of others, including fibroblasts, epithelial cells and lymphocytes (26). The pertussis toxin, islet-activating protein (IAP), binds to a class of GTP-binding proteins (G-proteins), inhibiting cell growth of some cell lines $(11,15)$. Even using the same cell lines, the degree of inhibition varies, however, depending upon the growth factors or agents used for stimulation $(11,15)$.

In this report, we have shown that IL-4 affected IC2 cells differently from IL-3 or GM-CSF. IL-4 shortens the Gl phase of the cell cycle. In contrast, TGF- $\beta$ and IAP showed inhibitory effects on the growth of IC2 cells. These two agents elongated the Gl phase but did not cause cell death.

\section{MATERIALS AND METHODS}

Materials. RPMI 1640 and FCS were obtained from GIBCO, Grand Island, NY, USA; penicillin $\mathrm{G}$ and kanamycin were from Meiji Seika Co., Tokyo; HEPES was from Sigma Chemical Co., St. Louis, MO, USA; propidium iodide was from Boehring Diagnostics, La Jolla, CA, USA; TGF- $\beta$ was from Collaborative Research, Inc, Lexington, MA, USA; [methyl $\left.-{ }^{3} \mathrm{H}\right]$ thymidine and $\left[a^{-32} \mathrm{P}\right]$ NAD were from Amersham International, Amersham, United Kingdom. RPMI 1640 was generally supplemented with $10 \mathrm{mM}$ HEPES, $0.2 \%$ sodium bicarbonate, $5 \times 10^{-5} \mathrm{M} 2 \mathrm{ME}, 100 \mathrm{units} / \mathrm{ml}$ penicillin $\mathrm{G}$ and $0.2 \mathrm{mg} / \mathrm{ml} \mathrm{kanamycin}$.

Mouse recombinant IL-3 (30) and IL-4 (10) were purified from serum-free culture supernatant fluids of COS-7 cells transfected with expression vectors carrying cDNAs for mouse IL-3 and mouse IL-4, respectively. Mouse recombinant GM-CSF (13) was purified from the culture supernatant fluid of yeast cells transfected with an expression vector carrying the cDNA for mouse GM-CSF as described previously (12). The purity of IL-3 and GM-CSF was more than $95 \%$ and that of IL-4 was about $50 \%$. Purification of IAP and activation of its Aprotomer was performed as described previously $(5,29)$.

Cells and growth conditions. Conditioned medium from Con A-stimulated mouse splenocytes was prepared as described previously (6). Multi-factor-dependent mast cell progenitor cell lines, IC2 and LT4, were cultured in RPMI 1640 containing 5\% FCS, and 50\% conditioned medium $(6,7)$. DNA synthesis was determined in triplicate samples as follows. Exponentially growing IC2 cells after 2 days of culture were washed extensively with RPMI 1640 containing $10 \%$ FCS and suspended in the same medium at $10^{5}$ cells $/ \mathrm{ml}$. A hundred $\mu \mathrm{l}$ of the suspension was mixed with $100 \mu \mathrm{l}$ of the above medium containing various concentra- 
tions of growth factors and cultured in 96-well microtiterplates for $21 \mathrm{~h}$ in a $\mathrm{CO}_{2}$ incubator. Then the cells were labeled with $1 \mu \mathrm{Ci} /$ well of $\left[{ }^{3} \mathrm{H}\right]$ thymidine for $3 \mathrm{~h}$.

Miscellaneous. Cell cycle analysis was performed as follows. The cells were washed twice with RPMI 1640 containing $10 \%$ FCS and mixed with a solution consisting of $50 \mu \mathrm{g} / \mathrm{ml}$ propidium iodide, $0.05 \% \mathrm{NP} 40,10 \mu \mathrm{g} / \mathrm{ml}$ RNase A and $0.1 \%$ sodium citrate. Flow cytometry was performed using a FACS IV (Becton Dickinson, Mountain View, CA, USA). Substrate(s) of IAP was analyzed by radiolabeling of membrane proteins with $\left[a{ }^{32} \mathrm{P}\right]$ NAD as described previously (18). Sodium dodecyl sulfate-polyacrylamide gel electrophoresis (SDSPAGE) was performed as described (9).

\section{RESULTS}

Difference between IL-4 and other growth factors in the ability to induce DNA synthesis. IC2 cells lose viability within $24 \mathrm{~h}$ when cultured in the absence of growth factors. IL-3, GM-CSF and IL-4 have the ability to induce DNA synthesis of IC2 cells (Fig. 1, ref. 8) and maintain viability of IC2 cells after 24 h cultivation. IL-3 and GM-CSF showed similar concentration dependence curves for induction of DNA synthesis in IC2 cells (Fig. 1A). The $\mathrm{ED}_{50}$ (the concentration of IL-3 or GM-CSF required for $50 \%$ stimulation of IC2 cells at $5 \times 10^{4}$ cells $/ \mathrm{ml}$ ) was ca. 5 pM. IL-4 stimulated IC2 cells in a different manner. The maximum level of DNA

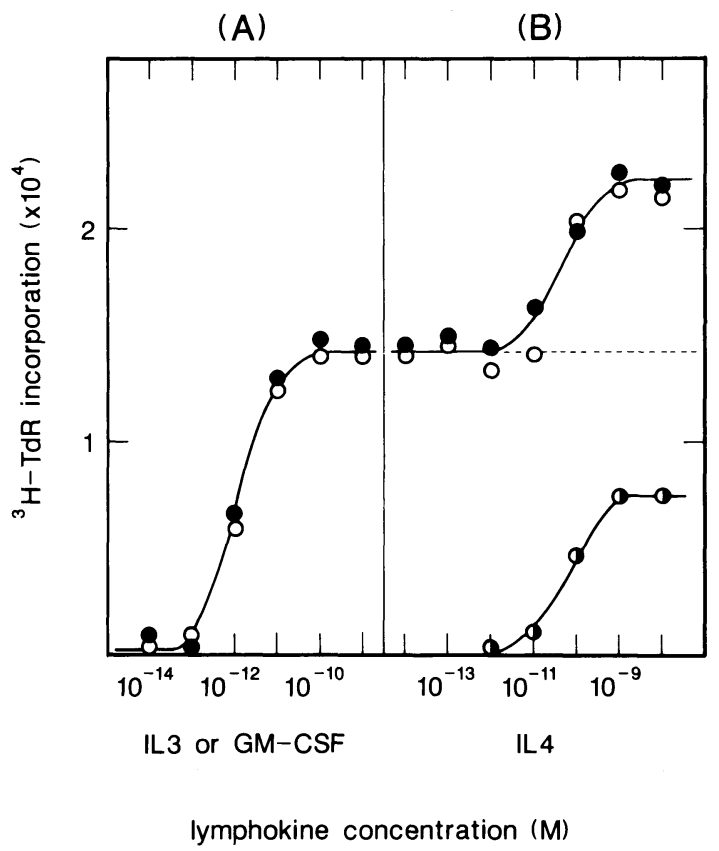

Fig. 1. DNA synthesis of IC2 cells induced by three growth factors. (A) IC2 cells $\left(10^{4}\right.$ cells in $\left.0.2 \mathrm{ml}\right)$ were cultured in RPMI 2640-10\% FCS with various concentrations of IL-3 ( $\bigcirc)$ or GM-CSF ( $\bullet$ ) for $21 \mathrm{~h}$ in 96-well microtiter plates, after which DNA synthesis was determined by pulse-labeling with $1 \mu \mathrm{Ci} /$ well of $\left[{ }^{3} \mathrm{H}\right]$ thymidine for $3 \mathrm{~h}$. (B) IC2 cells were cultured for $21 \mathrm{~h}$ with various concentrations of IL-4 in RPMI 1640-10\% FCS (๑) or in the same medium containing 1 nM IL-3 ( $\odot$ ) or 1 nM GM-CSF $(\bullet)$, after which DNA synthesis was determined by pulse-labeling with $\left[{ }^{3} \mathrm{H}\right]$ thymidine for $3 \mathrm{~h}$. 


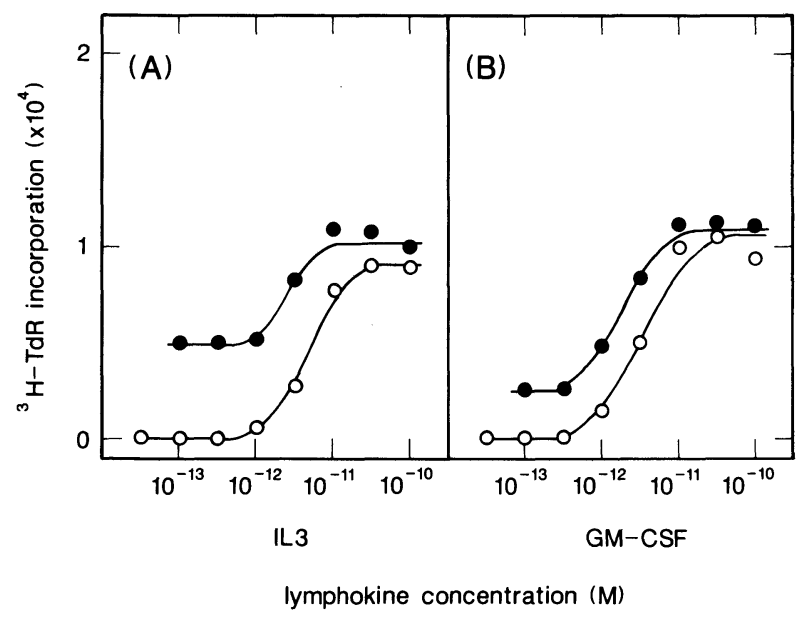

Fig. 2. IL-3 and GM-CSF induce DNA synthesis of IC2 cells in a similar manner. (A) IC2 cells were cultured with various concentrations of IL-3 in RPMI 1640-10\% FCS $(\bigcirc)$ or in the same medium containing $3 \mathrm{pM} \mathrm{GM-CSF}(\bullet)$ for $21 \mathrm{~h}$ followed by $3 \mathrm{~h}$ pulse-labeling with $1 \mu \mathrm{Ci} /$ well of $\left[{ }^{3} \mathrm{H}\right]$ thymidine. (B) Various concentrations of GM-CSF were used for stimulation of IC2 cells in the absence $(O)$ or presence of 3 pM IL-3 (•).

synthesis induced by IL-4 alone was always lower than that induced by IL-3 or GMCSF (Fig. IB). The ED S0 $_{50}$ IL-4 was ca. 100 pM, higher than that of IL-3 or GMCSF. IC2 cells were subcloned by limiting dilution. Each subclone responded

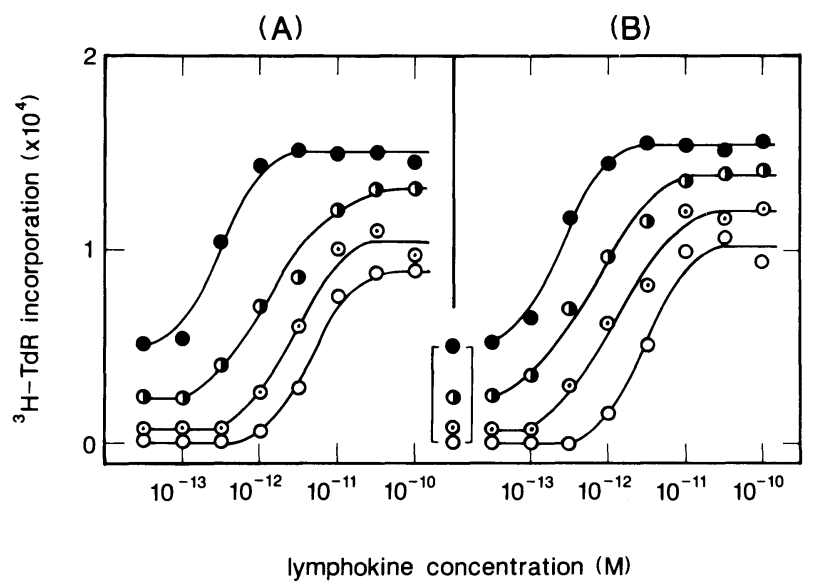

Fig. 3. Synergistic action of IL-4 and IL-3 or GM-CSF. IC2 cells were cultured for $21 \mathrm{~h}$ with various concentrations of IL-3 (A) or GM-CSF (B) in RPMI 1640-10\% FCS containing $0(O), 0.03(\odot), 0.3(\odot)$ or $3 \mathrm{nM}(\bullet)$ IL-4, and DNA synthesis was determined by pulse-labeling with $\left[{ }^{3} \mathrm{H}\right]$ thymidine for $3 \mathrm{~h}$. The symbols in brackets between (A) and (B) indicate DNA synthesis induced by IL-4 in the absence of IL-3 or GM-CSF. 


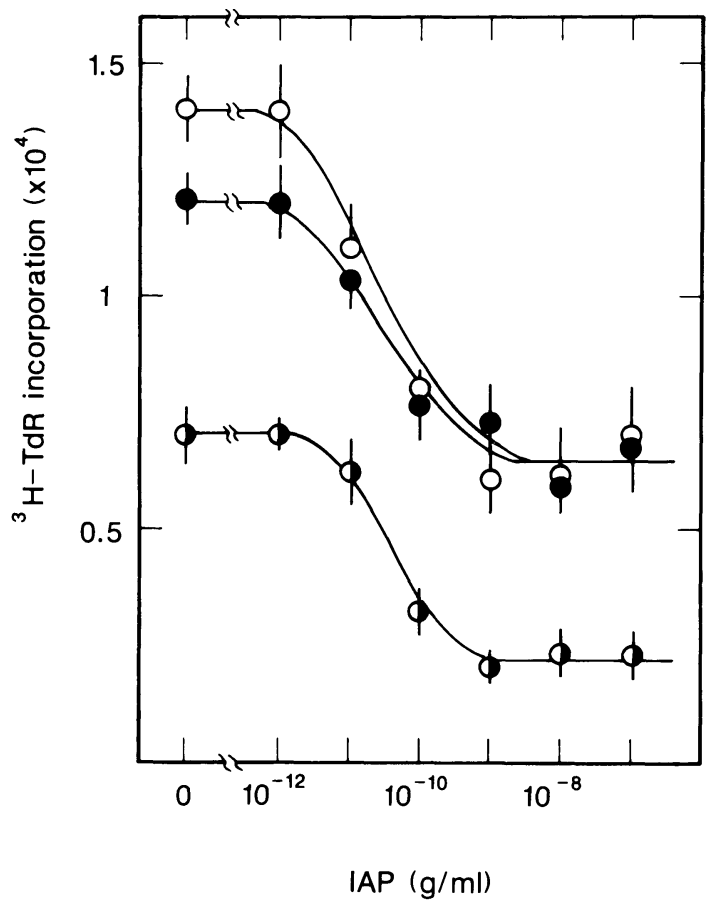

Fig. 4. Inhibitory effect of IAP on DNA synthesis of IC2 cells induced by IL-3, GM-CSF or IL-4. IC2 cells were cultured with various concentrations of IAP in RPMI-10\% FCS containing 100 pM IL-3 $(\bigcirc), 100 \mathrm{pM}$ GM-CSF (๑) or $1 \mathrm{nM} \mathrm{IL-4}(\bullet)$ for $21 \mathrm{~h}$ and pulse-labeled with $\left[{ }^{3} \mathrm{H}\right]$ thymidine for $3 \mathrm{~h}$.

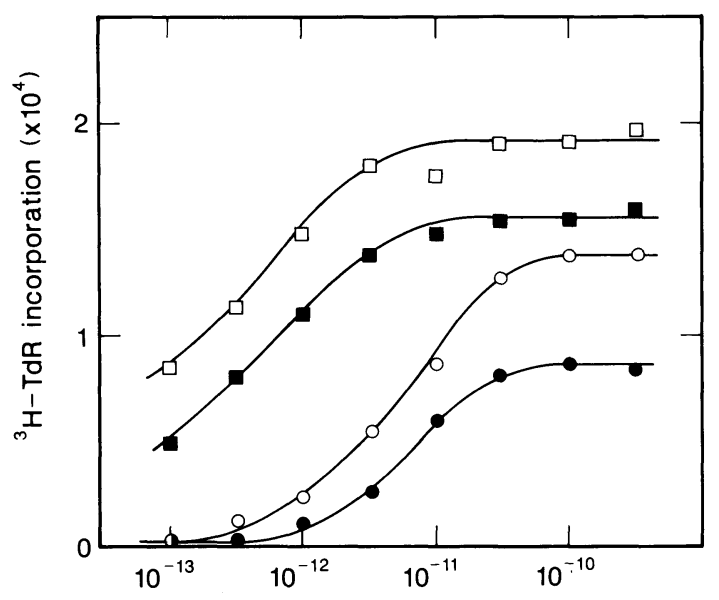

IL3 concentration (M)

Fig. 5. Inhibitory effect of IAP on DNA synthesis induced by various doses of IL-3 in the presence or absence of IL-4. IC2 cells were cultured with various concentrations of IL-3 $(\odot, \bullet)$ or a combination of $3 \mathrm{nM}$ IL-4 and various concentrations of IL-3 $(\square, \square)$ in RPMI 1640-10\% FCS in the absence $(\bigcirc, \square)$ or presence $(\bullet, \nabla)$ of $100 \mathrm{ng} / \mathrm{ml}$ IAP for $21 \mathrm{~h}$ and pulse-labeled with $\left[{ }^{3} \mathrm{H}\right]$ thymidine for $3 \mathrm{~h}$. 
similarly to the three growth factors, indicating that individual cells can respond to multiple growth factors.

When IC2 cells were stimulated with a combination of IL-4 and IL-3 or GM-CSF, the level of DNA synthesis was higher than that induced by only IL-3 or GM-CSF (Fig. 1B). In contrast, a combination of IL-3 and GM-SCF did not increase the maximum level of DNA synthesis, although suboptimal doses of IL-3 and GM-CSF additively stimulated the cells (Fig. 2).

IC2 cells were stimulated with IL-3 or GM-CSF in the presence of various concentrations of IL-4 (Fig. 3). The maximum level of DNA synthesis increased in an IL-4concentration-dependent manner as in Fig. 1B. In addition, the concentration dependence curve of stimulation obtained with IL-3 or GM-CSF shifted to the left in the presence of IL-4. About 1 pM IL-3 or GM-CSF induced the maximum level of DNA synthesis in the presence of $3 \mathrm{nM}$ IL-4.

IAP inhibits growth factor-induced DNA synthesis of IC2 cells. IC2 cells were cultured for $24 \mathrm{~h}$ with various concentrations of IAP in the presence of IL-3, GMCSF or IL-4. IAP inhibited DNA synthesis induced by the growth factors in a concentration-dependent manner (Fig. 4). The inhibitory effect was detected with $10 \mathrm{pg} / \mathrm{ml} \mathrm{IAP}$ and the maximum inhibition was obtained at $1 \mathrm{ng} / \mathrm{ml} \mathrm{IAP} \mathrm{or} \mathrm{more.}$

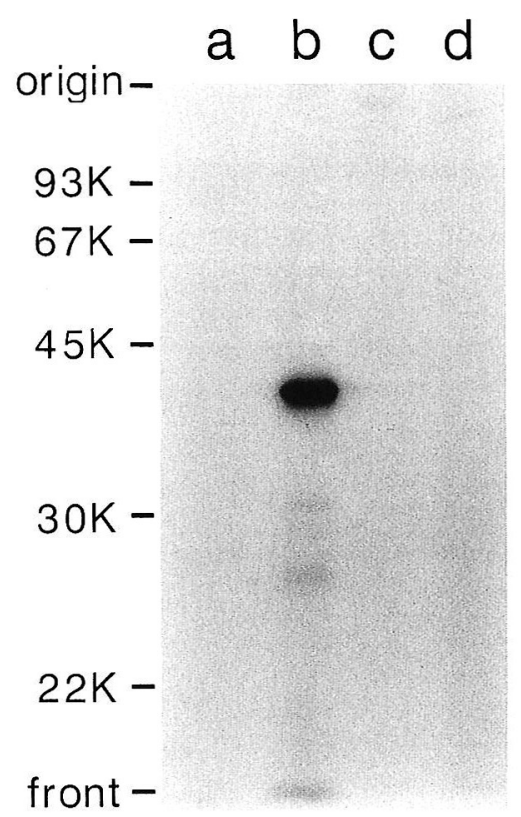

Fig. 6. ADP-ribosylation of 41-kDa protein induced by IAP in IC2 cells. IC2 cells were cultured at $5 \times 10^{5}$ cells $/ \mathrm{ml}$ in RPMI $1640-10 \%$ FCS containing 50 pM IL-3 in the absence $(\mathrm{a}, \mathrm{b})$ or presence $(\mathrm{c}, \mathrm{d})$ of $100 \mathrm{ng} / \mathrm{ml}$ IAP for $24 \mathrm{~h}$. The cells were collected and membrane fractions were prepared as described previously (18). Membrane proteins were incubated at $37^{\circ} \mathrm{C}$ for $60 \mathrm{~min}$ in the absence $(\mathrm{a}, \mathrm{c})$ or presence (b, d) of $166 \mu \mathrm{g} / \mathrm{ml}$ preactivated IAP in $2.5 \mathrm{mM} \mathrm{MgCl} 2,1 \mathrm{mM}$ ATP, $10 \mathrm{mM}$ thymidine, $1 \mathrm{mM}$ DTT, $3 \mathrm{mM}$ phosphoenolpyruvate, $10 \mu \mathrm{g} / \mathrm{ml}$ pyruvate kinase, $10 \mu \mathrm{M}$ [ $\left.a_{-}{ }^{32} \mathrm{P}\right] \mathrm{NAD}(8.3 \mathrm{Ci} / \mathrm{mmol})$, and $100 \mathrm{mM}$ potasium phosphate (pH 7.6). Samples were resoled by SDS-PAGE and in vitro substrates for IAP were detected by autoradiography. The numbers on the left side indicate the positions of molecular weight markers. 
TABLE 1. EFFECT OF TGF- $\beta$ ON DNA SYNTHESIS OF IC 2 CELLS INDUCED BY VARIOUS GROWTH FACTORS ${ }^{\mathrm{a}}$.

\begin{tabular}{lcc}
\hline \multirow{2}{*}{ Reagents } & \multicolumn{2}{c}{$\left[{ }^{3} \mathrm{H}\right]$ thymidine incorporation } \\
\cline { 2 - 3 } & - & + TGF- $\beta(100 \mathrm{pM})$ \\
\hline IL-3 $\left(10^{-10} \mathrm{M}\right)$ & $238 \pm 34$ & $312 \pm 12$ \\
GM-CSF $\left(10^{-10} \mathrm{M}\right)$ & $10234 \pm 646$ & $6458 \pm 342$ \\
IL-4 $\left(10^{-9} \mathrm{M}\right)$ & $13231 \pm 574$ & $8468 \pm 171$ \\
IL-3+IL-4 & $8607 \pm 236$ & $2151 \pm 91$ \\
GM-CSF+IL-4 & $17091 \pm 1852$ & $10991 \pm 859$ \\
\end{tabular}

aDNA synthesis was determined in triplicate samples according to the method described in Materials and Methods and is expressed with SEM.

The inhibition by IAP was always incomplete, however (Fig. 4), and inhibition was observed at all doses of IL-3 (Fig. 5). In addition, IAP also partially inhibited DNA synthesis induced by IL-3 and IL-4 (Fig. 5). IAP at $\mathrm{ng} / \mathrm{ml}$ orders inhibited IL-4-induced DNA synthesis by 70\% (Fig. 4). IAP affected to lesser extents DNA synthesis dependent upon IL-3 or GM-CSF. IAP treatment did not decrease the viability of IC2 cells, indicating that the inhibitory effect of IAP was not due to toxicity of the reagent. We have excluded the following possibilities (data not shown): (a) IAP inhibits binding of growth factors to IC2 cells, (b) IAP inhibits uptake of $\left[{ }^{3} \mathrm{H}\right]$ thymidine into stimulated cells. IAP inhibited growth of IC2 cells as measured by cell number (see below).

To confirm that IAP ADP-ribosylated membrane proteins during the incubation, we performed in vitro ADP-ribosylation using a membrane fraction prepared from IC 2 cells cultured for $24 \mathrm{~h}$ with $1 \mathrm{nM}$ IL-3 in the presence or absence of $100 \mathrm{ng} / \mathrm{ml}$

(A)

(B)

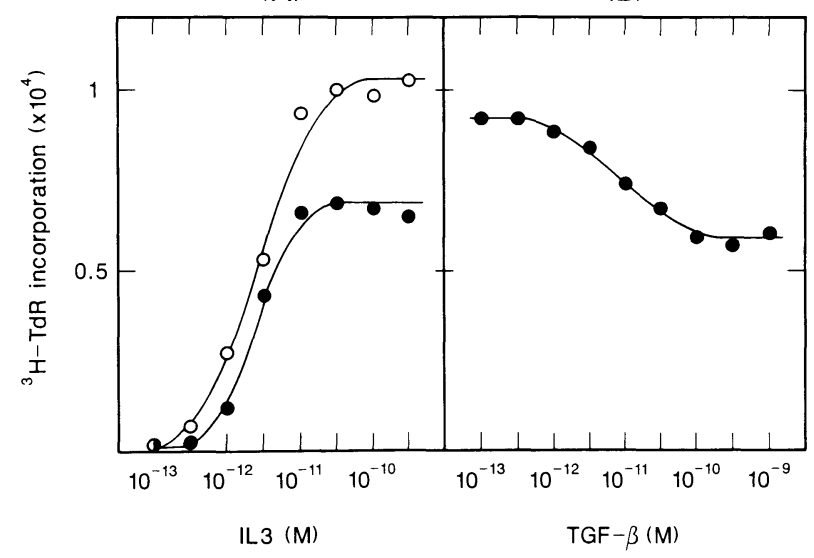

Fig. 7. Inhibition of DNA synthesis of IC2 cells by TGF- $\beta$. (A) IC2 cells were cultured with various concentrations of IL-3 in RPMI 1640-10\% FCS $(O)$ or in the same medium containing 100 pM TGF- $\beta(\bullet)$ for $21 \mathrm{~h}$ followed by $3 \mathrm{~h}$ pulse-labeling with $1 \mu \mathrm{Ci} /$ well $\left[{ }^{3} \mathrm{H}\right]$ thymidine. (B) IC2 cells were cultured with various concentrations of TGF- $\beta$ in RPMI 1640-10\% FCS containing 100 pM IL-3 for $21 \mathrm{~h}$ followed by $3 \mathrm{~h}$ pulse-labeling with $1 \mu \mathrm{Ci} /$ well of $\left[{ }^{3} \mathrm{H}\right]$ thymidine. 


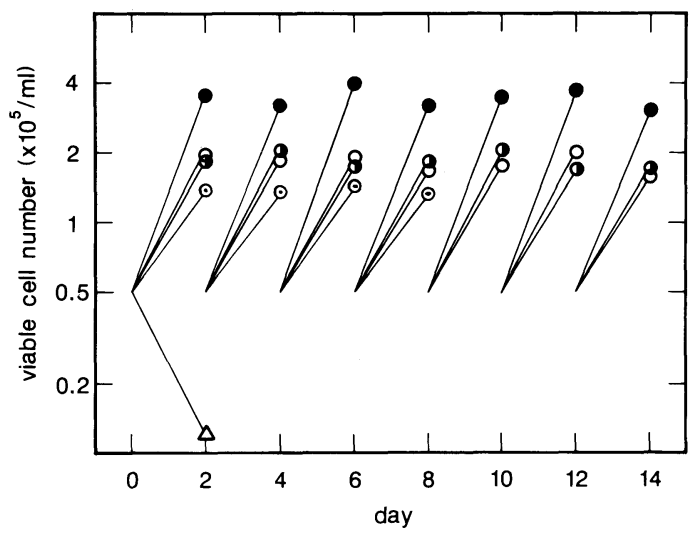

Fig. 8. Long-term culture of IC2 cells with various growth factors. IC2 cells were cultured at $5 \times 10^{4}$ cells/ml in RPMI 1640-10\% FCS containing $1 \mathrm{nM} \mathrm{IL-3} \mathrm{( \bigcirc ),} 1 \mathrm{nM} \mathrm{IL-4}(\triangle), 1 \mathrm{nM}$ IL-3 and $1 \mathrm{nM}$ GM-CSF (๑), $1 \mathrm{nM}$ IL-3 and $100 \mathrm{ng} / \mathrm{ml}$ IAP $(\odot)$ or $1 \mathrm{nM}$ IL-3 and $1 \mathrm{nM}$ IL-4 $(\bullet)$. Cell numbers were determined 2 days after cultivation began and the cells were cultured further under the same conditions.

IAP. As shown in Fig. 6 (lane b), IAP ADA-ribosylated a 41-kDa protein in vitro in a membrane fraction from cells which had been cultured in the absence of IAP. In contrast, the 41-kDa protein was not ADP-ribosylated in vitro with membrane fractions from cells cultured in the presence of IAP (Fig. 6, lane d). This indicates that the protein was fully ADP-ribosylated in vivo.

TGF- $\beta$ inhibits DNA synthesis of IC2 cells. IC2 cells were stimulated for $24 \mathrm{~h}$ with various growth factors in the presence or absence of $100 \mathrm{pM}$ human TGF- $\beta$.

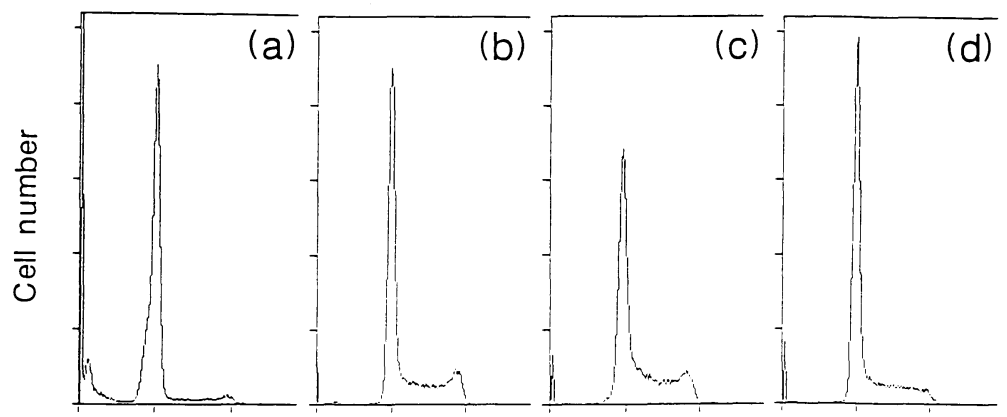

Fluorescence intensity (DNA content)

Fig. 9. Cell cycle analysis of IC2 cells stimulated by various growth factors. IC2 cells which had been cultured for 3 days without changing the conditioned medium were collected (a). Cells cultured with IL-3 (b), with IL-3 and IL-4 (c) or with IL-3 and IAP (d) were collected on day 8. The cells were washed and mixed with a solution consisting of $50 \mu \mathrm{g} / \mathrm{ml}$ propidium iodide, $0.05 \% \mathrm{NP} 40,10 \mu \mathrm{g} / \mathrm{ml} \mathrm{RNase} \mathrm{A}$ and $0.1 \%$ sodium citrate. Cell cycle analysis was performed by flow cytometry using a FACS IV. 
TGF- $\beta$ inhibited DNA synthesis induced by IL-3, GM-CSF, IL-3 plus IL-4 or GMCSF plus IL-4 by 30 to $40 \%$, but more severely (ca. $70 \%$ ) inhibited that induced by IL-4 (Table 1). Inhibition of DNA synthesis by TGF- $\beta$ was dose-dependent and reached a plateau level at $100 \mathrm{pM}$ (Fig. 7).

Effects of IL-3, GM-CSF, IL-4, IAP and TGF- $\beta$ on long-term growth of IC2 cells. The abilities of the three growth factors to support long-term growth of IC2 cells were examined (Fig. 8). IC2 cells grew continuously in the presence of IL-3 or GM-CSF when appropriately diluted every two days. The doubling time was ca. $25 \mathrm{~h}$ for cultures with a sufficient concentration of IL-3 or GM-CSF. In contrast, IL-4 did not support the continuous growth of IC2 cells. In the presence of IL-4, the cells survived for $24 \mathrm{~h}$ and divided once, but eventually died after 2 days of incubation. IL-4, however, enhanced the IL-3- or GM-CSF-dependent growth of IC2 cells. Sufficient concentrations of IL-3 or GM-CSF in the presence of $1 \mathrm{nM}$ IL-4 allowed IC2 cells to grow rapidly, with a doubling time of ca. $17 \mathrm{~h}$. When IC2 cells were cultured with a sufficient concentration of IL-3 in the presence of $100 \mathrm{ng} / \mathrm{ml}$ IAP, the cells grew exponentially with a doubling time of ca. $30 \mathrm{~h}$.

Cell cycle analysis was performed with exponentially growing IC2 cells under various conditions by staining DNA with propidium iodide (Fig. 9). While the fraction of G1 cells was 59\% for a culture stimulated by IL-3 (Fig. 9b), it decreased to $49 \%$ for that co-stimulated by IL-3 and IL-4 (Fig. 9c). On the other hand, IAP increased the fraction of G1 cells growing with IL-3 to 70\% (Fig. 9d) and that of those growing with IL-3 and IL-4 to 56\% (see Table 2). From these results, we calculated the length of G1 phase in the cell cycle (Table 2, Exp. 1). The results demonstrated that the length of $\mathrm{G} 1$ phase varied with treatment, whereas the length of $S+G 2+M$

TABLE 2. EFFECTS OF IL-4, TGF- $\beta$ AND IAP ON THE CELl CYCLE of IC2 CELls.

\begin{tabular}{|c|c|c|c|c|}
\hline \multirow{2}{*}{ reagent } & \multirow{2}{*}{$\mathrm{Td}(\mathrm{h})^{\mathrm{a}}$} & \multirow{2}{*}{ G1 $(\%)^{b}$} & \multicolumn{2}{|c|}{ cell cycle length $(h)^{c}$} \\
\hline & & & G1 & $\mathrm{S}+\mathrm{G} 2+\mathrm{M}$ \\
\hline \multicolumn{5}{|l|}{ Experiment 1} \\
\hline IL-3 & $25 \pm 1$ & $59 \pm 5$ & $13 \pm 1$ & $12 \pm 1$ \\
\hline IL-3 + IL-4 & $17 \pm 1$ & $49 \pm 5$ & $7 \pm 1$ & $10 \pm 1$ \\
\hline IL-3 + IAP & $30 \pm 2$ & $70 \pm 5$ & $19 \pm 2$ & $11 \pm 1$ \\
\hline IL-3 + IL-4 + IAP & $23 \pm 1$ & $56 \pm 5$ & $11 \pm 1$ & $12 \pm 1$ \\
\hline \multicolumn{5}{|l|}{ Experiment 2} \\
\hline IL-3 & $20 \pm 2$ & $45 \pm 5$ & $8 \pm 1$ & $12 \pm 2$ \\
\hline $\mathrm{IL}-3+\mathrm{TGF}-\beta$ & $26 \pm 2$ & $57 \pm 5$ & $13 \pm 2$ & $13 \pm 2$ \\
\hline \multicolumn{5}{|l|}{ Experiment 3} \\
\hline IL-3 & $26 \pm 2$ & $n d^{d}$ & nd & nd \\
\hline $\mathrm{IL}-3+\mathrm{TGF}-\beta$ & $30 \pm 3$ & nd & nd & nd \\
\hline IL-3 + IAP & $29 \pm 1$ & nd & nd & nd \\
\hline $\mathrm{IL}-3+\mathrm{TGF}-\boldsymbol{\beta}+\mathrm{IAP}$ & $30 \pm 2$ & nd & nd & nd \\
\hline \multicolumn{5}{|c|}{$\begin{array}{l}\text { The mean doubling time (Td) was determined from growth line slope (Fig. 8) and is expressed with SE } \\
\text { caused in determination of the slope. } \\
\text { The fraction of cells in G1 phase was determined by flow cytometry with duplicate samples (Fig. 9) } \\
\text { using Dean's method (1). } \\
\text { The length of the G1 period was calculated from populations of cells in G1 phase according to the equa- } \\
\text { tion } \mathrm{Td} \times[1-\log \{2-\mathrm{F}(\mathrm{G} 1)\} / \log 2] \text {, in which } \mathrm{F}(\mathrm{G} 1) \text { is the fraction of cells in G1 phase (31). } \\
\text { d Not determined. }\end{array}$} \\
\hline
\end{tabular}




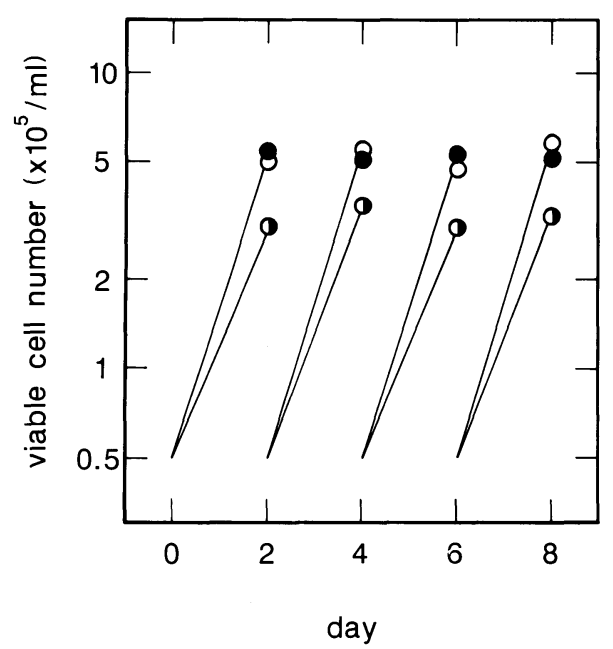

Fig.10. Effects of IL-3, IL-4 and IAP on the growth of LT4 cells. Long-term cultures of LT4 cells with $1 \mathrm{nM}$ IL-3 $(\odot), 1 \mathrm{nM}$ IL-3 and $1 \mathrm{nM}$ IL-4 (๑), and $1 \mathrm{nM}$ IL-3 and $100 \mathrm{ng} / \mathrm{ml} \mathrm{IAP} \mathrm{( \odot )} \mathrm{were} \mathrm{examined}$ as described in Fig. 8.

was constant.

TGF- $\beta$ also reduced the growth rate of IC 2 cells (Table 2). It should be noted that the growth rate of control IC2 cells incubated with IL-3 alone varied from experiment to experiment (Table 2, Exp. 2 and 3). This variation did not affect of the major conclusions of this study, however. Simultaneous addition of IAP and TGF- $\beta$ did not cause stronger inhibition than that caused by either one alone.

Another multi-factor-dependent myeloid cell line, LT4 (7), grows more rapidly than IC2, with a doubling time of ca. $14 \mathrm{~h}$ (Fig. 10). The IL-3-dependent growth of LT4 cells was not affected by IL-4, although DNA synthesis of these cells was stimulated by IL-4 alone. IAP inhibited the growth of LT4 cells. The doubling time of LT4 cells cultured with sufficient concentrations of IL-3 in the presence of $100 \mathrm{ng} / \mathrm{ml}$ IAP was ca. $19 \mathrm{~h}$ (Fig. 10), indicating that IL-3-induced growth of LT4 cells is also IAP-sensitive.

\section{DISCUSSION}

IL-3 and GM-CSF specifically bind to distinct receptors $(16,17,21,22,28)$. The IC2 cells used in this study express both IL-3 and GM-CSF receptors. We have recently shown that IL-3 but not GM-CSF rapidly induces tyrosine phosphorylation of a membrane glycoprotein, gpp150 (8). Although the receptors for these two growth factors and the early biochemical events induced by them are distinct, the stimulatory effects of IL-3 and GM-CSF on IC2 cells appear quite similar, as described above. These two growth factors induced DNA synthesis of IC2 cells in a similar concentration-dependent manner and could support the long-term growth of IC2 cells. When the cells were co-stimulated with a combination of IL-3 and GM-CSF, the total concentrations of the two growth factors required for the induction of DNA synthesis to $50 \%$ of the maximum were always ca. $5 \mathrm{pM}$ regardless of the ratio of the two growth factors. This value is the same as that obtained with either IL-3 or 
GM-CSF alone, suggesting that IL-3 and GM-CSF induce DNA synthesis of IC2 cells through common downstream processes although the initial events are different.

IL-4 induced transient DNA synthesis but could not support long-term growth of IC2 cells. Cells incubated with IL-4 alone died within 2 days, suggesting that these cells initiated DNA synthesis and completed the cell cycle once but could not enter the next round of the cell cycle. IL-4 augmented the effect of IL-3 and GM-CSF on IC2 cells: 1) the maximum rate of DNA synthesis increased, 2) sensitivity to IL-3 or GM-CSF increased, and 3) the length of the G1 phase was shortened. Furthermore, IL-4-induced DNA synthesis is more susceptible to inhibition by IAP and TGF- $\beta$ than other growth factor-induced DNA synthesis. It is thus suggested that IL-4 affects IC2 cells through a unique mechanism.

When IC2 cells were cultured for 3 days or more without changing the conditioned medium, the viability of the cells gradually decreased and the fraction of cells in G1 phase increased (Fig. 9a). This suggested that IC2 cells could not enter S phase but died in G1 phase in the absence of sufficient amounts of growth factors. It has been proposed that every cell passes through a restriction point in the late G1 phase before entering $S$ phase $(19,20)$. Only cells that receive sufficient stimulating signals can go through the restriction point; others stay in G1 phase. IL-3 and GM-CSF are considered to be progression factors which stimulate IC2 cells to go through the restriction point and to round the cell cycle. The threshold of the restriction point to enter S phase may be lowered by IL-4 (Figs. 1B, 3). Augmentation of the growth rate by IL- 4 was not observed in LT 4 cells, although these cells express receptors for IL-4 and can respond to IL-4 alone (unpublished observation). Similar results were obtained with a variant of IC2 which also grew more rapidly than IC2 with a doubling time of ca. $14 \mathrm{~h}$ in a sufficient concentration of IL-3 alone (unpublished observation). The hypothetical growth enhancing signal(s) in IC2 cells induced by stimulation with IL-4 in IC2 cells might be constitutively generated in LT4 and the variant of IC2.

IAP has been shown to inhibit DNA synthesis induced by certain growth factors in fibroblast cells $(11,15)$. In contrast, IAP did not inhibit DNA synthesis of an interleukin 2-dependent $\mathrm{T}$ cell clone, K23, at any concentration (unpublished observation). As shown above, IAP commonly inhibited DNA synthesis in myeloid cells induced by either one of or a combination of IL-4, IL-3 and GM-CSF. An interesting feature of the IAP effect is that IAP did not completely inhibit DNA synthesis, although a 41-kDa substrate was fully ADP-ribosylated in IAP-treated cells (Figs. 4-6). A similar IAP effect was observed with fibroblasts $(11,15)$. Other features of the IAP effect are: 1) IAP did not cause cell death, 2) the cells grew slowly in the presence of IAP, and 3) IAP increased the fraction of cells present in the G1 phase of the cell cycle. The effect of TGF- $\beta$ on IC2 cells is apparently similar to that of IAP. However, TGF- $\beta$ has been reported to inhibit the proliferative response of T cells (26) whereas IAP did not (unpublished observation). This suggests that the target biochemical reactions of the two growth-inhibitory agents in IC2 cells are different. The growth inhibition by IAP does not necessarily suggest that an IAPsensitive $G$ protein(s) is directly involved in regulation of the cell cycle.

Acknowledgements. We thank E. Abe, F. Sameshima and H. Izumi for their excellent technical assistance. This work was supported by Special Coordination Funds for Promoting Science and Technology from the Science and Technology Agency of Japan and by Grants-in-Aid from the Ministry 
of Education, Science and Culture of Japan.

\section{REFERENCES}

1. Dean, P.N. and J.H.JetT. Mathematical analysis of DNA distributions derived from flow microfluoremetry. J. Cell Biol. 60, 523-527, 1974

2. Dexter, T.M., J. Garland, D. Scott, E. Scolnick and D. Metcalf. Growth of factor-dependent hemopoietic precursor cell lines. J. Exp. Med. 152, 1036-1047, 1980

3. HAPEl, A.J., H.S. WARREN and D.A. Hume. Different colony-stimulating factors are detected by the "interleukin-3"-dependent cell lines, FDC-P1 and 32Dc1-23. Blood 64, 786-790, 1984

4. IHLE, J.N. and Y. WEINSTEIN. Immunological regulation of hematopoietic/lymphoid stem cell differentiation by interleukin 3. Adv. Immunol. 39, 1-50, 1986

5. Katada, T., M. Tamura and M. Ui. The A promotor of islet-activating protein, pertussis toxin, as an active peptide catalyzing ADP-ribosylation of a membrane protein. Arch. Biochem. Biophys. 224, 290-298, 1983

6. Koyasu, S., H. Nakauchi, K. Kitamura, S. Yonehara, K. OKumura, T. Tada and I. Yahara. Production of interleukin 3 and $\gamma$-interferon by an antigen-specific mouse suppressor $\mathrm{T}$ cell clone. J. Immunol. 134, 3130-3136, 1985

7. Koyasu, S., J. YodoI, T. Nikaido, Y. Tagaya, Y. TANiguchi, T. Honjo and I. Yahara. Expression of interleukin 2 receptors on interleukin 3-dependent cell lines. J. Immunol. 136, 984-987, 1986

8. Koyasu, S., A. Tojo, A. Miyajime, T. Akiyama, M. Kasuga, A. Urabe, J. Schreurs, K-I. Arai, F. TAKAKU and I. YAHARA. Interleukin 3-specific tyrosine phosphorylation of a membrane glycoprotein of Mr 150,000 in multi-factor-dependent myeloid cell lines. EMBO J. 6, 3979-3984, 1987

9. LAEMmLE, U.K. Cleavage of structural proteins during the assembly of the head of bacteriophage T4. Nature 227, 680-685, 1970

10. Lee, F., T Yokota, T. Otsuka, P. Meyerson, D. Villaret, R. Coffman, T. Mosmann, D. RenNick, N. Roehm, C. Smith, A. Zlotnik and K.-I. ARAi. Isolation and characterization of a mouse interleukin cDNA clone that expresses B-cell stimulating factor 1 activities and T-cell- and mast-cell-stimulating activities. Proc. Natl. Acad. Sci. USA. 83, 2061-2065, 1986

11. Letterio, J.J., S.R. Coughlin and L.T. Williams. Pertussis toxin-sensitive pathway in the stimulation of c-myc expression and DNA synthesis by bombesin. Science 234, 1117-1119, 1986

12. Miyajima, A., K. Otsu, J. Schreurs, M.W. Bond, J.S. Abrams and K.-I. Arai. Expression of murine and human granulocyte-macrophage conony-stimulating factors in $S$. cerevisiae: Mutagenesis of the potential glycosylation sites. EMBO J. 5, 1193-1197, 1986

13. Miyatake, S., T. Otsuka, T. Yokota, F. Lee and K.-I. Arai. Structure of the chromosomal gene for granulocyte-macrophage colony stimulating factor: comparison of the mouse and human genes. EMBO J. 4, 2561-2568, 1985

14. Mosmann, T.R., M.W. Bond, R.L. Coffman, J. Ohara and W.E. Paul. T-cell and mast cell lines respond to B-cell stimulatory factor 1. Proc. Natl. Acad. Sci. USA. 83, 5654-5658, 1986

15. Murayama, T. and M.Ui. Possible involvement of a GTP-binding protein, the substrate of isletactivating protein, in receptor-mediated signaling responsible for cell proliferation. J. Biol. Chem. 262, 12463-12467, 1987

16. Nicola, N.A. and D. Metcalf. Binding of iodinated multipotential colony-stimulating factor (interleukin-3) to murine bone marrow cells. J. Cell. Physiol. 128, 180-188, 1986

17. Ohara, J. and W.E. Paul. Receptors for B-cell stimuratory factor-1 expressed on cells of hematopoietic lineage. Nature 325, 537-540, 1987

18. Oкалima, F. and M. Ui. ADP-ribosylation of the specific membrane protein by Islets-activating protein, pertussis toxin-assocated with inhibition of a chemotactic peptide-induced arahidonate release in neutrophils. J. Biol. Chem. 259, 13863-13871, 1984

19. PARdeE, A.B. A restiction point for control of normal animal cell proliferation. Proc. Natl. Acad. Sci. USA. 71, 1286-1290, 1974

20. Pardee, A.B., R. Dubrow, J.L. Hamlin and R.F. Kletzien. Animal cell cycle. Ann. Rev. Biochem. 47, 715-759, 1978

21. PalASZYNSKi, E.W. and J.N. IhLE. Evidence for specific receptors for interleukin 3 on lym- 
phokine-dependent cell lines established from long-term bone marrow cultures. J. Immunol. 132, 1872-1878, 1984

22. Park L.S., D. Friend, K. Grabstein and D.L. Urdal. Characterization of the high-affinity cell surface receptor for murine B-cell-stimulating factor 1. Proc. Natl. Acad. Sci. USA. 84, 16691673,1987

23. Schrader, J.W., S.J. Lewis, I. Clark-lewis and J.G. Culvenor. The persisting (P) cell: Histamine content, regulation by a $\mathrm{T}$ cell-derived factor, origin from a bone marrow precursor, and relationship to mast cells. Proc. Natl. Acad. Sci. USA. 78, 323-327, 1981

24. Schrader, J.W. The panspecific hemopoietin of activated T lymphocytes (interleukin-3). Ann. Rev. Immunol. 4, 205-230, 1986

25. Sideras, P. and R. Palacios. Bone marrow pro-T and pro-B lymphocyte clones express functional receptors for interleukin(IL)3 and IL4/BSF-1 and nonfunctional receptors for IL2. Eur. $J$. Immunol. 17, 217-221, 1987

26. Sporn, M.B., A.B. Roberts, L.M. WAKeffeld and B. De Crombrugghe. Some recent advances in the chemistry and biology of transforming growth factor- $\beta$. J. Cell Biol. 105, 1039-1045, 1987

27. Tertian, G., Y.-P. Yung, D. GuY-Grand and M.A.S. Moore. Long-term in vitro culture of murine mast cell. I. Description of a growth factor-dependent culture technique. J. Immunol. 127, 788-790, 1981

28. WAlKer, F. and A.W. Burgess. Specific binding of radioiodinated granulocyte-macrophage colony-stimulating factor to hemopoietic cells. EMBO J. 4, 933-939, 1985

29. Yajima, M., K. Hosoda, Y. Kanbayashi, T. Nakamura, K. Norimori, Y. Mizushima, Y. NaKase and M. UI. Islet-activating protein (IAP) in Bordetella pertussis that potentiates insulin secretory responses of rats. Purification and Characterization. J. Biochem. 83, 295-303, 1978

30. Yokota, T., F. Lee, D. Rennick, C. Hall, N. Arai, T. Mosmann, G. Nabel, H. Cantor and K.I. ARAI. Isolation and characterization of a mouse cDNA clone that expresses mast-cell growthfactor activity in monkey cells. Proc. Natl. Acad. Sci. USA. 81, 1070-1074, 1984

31. Yoshikawa, H. and N. Sueoka. Sequential replication of Bacillus subtilis chromosome, I. Comparison of marker frequencies in exponential and stationary growth phases. Proc. Natl. Acad. Sci. USA. 49, 559-566, 1963

(Received for publication, February 16, 1989 and in revised form, May 23, 1989) 